\title{
c ）人工気管による気管および気管分岐部の再建
}

\author{
松原 義人, 池田貞 雄
}

\section{1.はじめに}

われわれは, 現在までに気管切除10例および 気管分岐部切除11例に対して気道再建術を行っ ている。そのうち，切除範囲が広範で直接吻合 による気道再建が困難な症例に対して, 人工気 管による気道再建術を昭和 54 年から 12 例に行っ た。当初は Neville 人工気管を使用していたが, 動物実験および臨床成績の検討から, Neville 人工気管は可撓性に乏しいので，吻合部の離開 や人工気管の逸脱が起こると考えられた。その 後, 可撓性や伸縮性に富む桂型人工気管を開発 し, 昭和57年から臨床例にも応用してきた。

\section{2. 対象および成績}

人工気管による気道再建例の原疾患は, 肺癌 7 例 (うち再発 2 例), 気管癌 3 例, 甲状腺癌 1 例, 結核性肉芽腫 1 例で, 大多数は悪性腫㿠で あった。術式の内訳は, 気管の管状切除 4 例, 気管分岐部切除 8 例であった。

気管の切除範囲は, 気管の管状切除群では肺 癌の術後再発例の 8 リングを除いて10〜19リン グであった。一方, 気管分岐部切除群のうち右 肺上葉管状切除 2 例では $8 \sim 9$ リング, 右肺管 状剔除 4 例では 4 リングの 1 例を除いて $7 \sim 8$ リング，気管分岐部切除のみ 2 例では 5,8 リ ングであった。

使用した人工気管の内訳は, straight type が Neville 型 5 例と桂型 2 例, curved type 桂型 1 例および bifurcated type が Neville 型 2 例と 桂型 2 例であった。

人工気管による重篤な術後合併症には, 吻合 部の離開, 肉芽形成による気道狭窄や感染, さ らに人工気管の逸脱, 大血管の損傷などがあげ られる。自験例では人工気管に起因する合併症

京都桂病院呼吸器センター
から死亡したものは，気管・腕頭動脈廔，気管・ 肺動脈瘻が各 1 例, 人工気管の逸脱 2 例, 膿胸 1 例であった。

人工気管による気道再建術の生存期間は, 6 力月以内 7 例, 15 力月 3 例, 25力月 1 例, 43力 月 1 例で, 現在までに全例が死亡した。前述の 合併症による死亡 5 例を除くと, その死因は他 病死 4 例, 癌死 3 例であった。

\section{3. 考 察}

気管および気管分岐部の再建は, 端々吻合や 端側吻合などの直接吻合によることが最善であ る。しかし, 諸種の気管や肺の授動術を行って も,気管や気管支の直接吻合が困難な場合には, 切除を諦めるか, 病変部位で吻合せざるを得な い。このような症例に対してわれわれは, 人工 気管による気道再建術を行った。

人工気管の適応は, (1) 原則として悪性腫湯に 限る, (2) 直接吻合が困難な場合, すなわち, a ) 10 リング以上の気管管状切除例, b ) 広範囲の 気管分岐部切除例, c ) 癌再発例の気道再建, (3) 気道狭窄による切迫室息例などである。

人工気管による合併症に対する予防策とし て, 感染予防, マーレックス・メッシュや生体 組織による吻合部の補強, 人工気管の改良, 大 血管の周囲を Lyodura や Gore-tex の soft tissue patchによる被覆保護などがあげられる。 また対策として, 肉芽にはレーザー焼灼, 離開・ 逸脱には気道内 stent を插入，大血管損傷には 再手術などを考慮している。

\section{4.おわりに}

人工気管による気道再建の手技は容易である が，その成績はいまだ不良である。さらにわれ われは吻合部の感染を防止する新しい人工気管 を考案し，現在実験的に検討中である。 